\title{
FOREST FIRE NEWS ANALYSIS IN SUMATERA-KALIMANTAN IN REPUBLIKA.CO.ID AND BHARIAN.COM.MY
}

\author{
Muhammad Ruslan Ramli \\ Esa Unggul University \\ Dasad Latif \\ Hasanuddin University \\ Youna Chatrine Bachtiar \\ Esa Unggul University
}

Correspondence email: ruslan.ramli@esaunggul.ac.id

\begin{abstract}
Pollution from smoke haze ignited from forest fires in Indonesia has been a recurrent annual problem among neighboring countries of South East Asia. This study discusses news about forest and land fires in Sumatra and Kalimantan, which were published on republika.co.id and bharian.com.my. This calamity received great attention because of its damaging consequences for other countries. Fires are considered a potential threat to the environmental development because of their effects to the ecosystem and the impact of carbon emission on biodiversity. This study aims to describe news frame republika.co.id and bharian.com.my for forest and land fires in Sumatra and Kalimantan. Using descriptive-qualitative forwarded by Robert Entman's framing analysis model, analyzing the root of the problem, the cause of the problem, moral judgment, and recommendations. Research result revealed differences in attitudes between republika.co.id and bharian.com.my towards this case. On the cause of the problem issue, moral judgment, and recommendations, republika.co.id's judgement are very firm, systematic, and detailed compared to bharian.com.my which appeared to technical and normative ones. On the issue of the root of the problem, the attitude of both of them blamed forest burners and the role of companies as actors.
\end{abstract}

Keywords: Forest and land fires; news value; news frame; framing elements.

\section{INTRODUCTION}

Climate change has brought uncertain world weather that has caused related changes in the natural climate processes. Natural disasters are adverse threatening events that occur due to natural processes of mother-nature. These natural geological processes of the earth include floods, hurricanes, volcanic eruptions, earthquakes, tsunamis and storms. And these processes will not be considered a disaster if it does not come with profound environmental damage, 
habitat change and loss of human lives. Similarly, man-made disasters, whether intentionally or unintentionally, has no less danger and one classic example is forest fire.

In general, forest fires is the burning of forests caused by natural circumstances like lightning, or when there is a long period of drought without rain for months, the forests or grasses are cluttered with dry leaves and twinges, and by the slightest friction and spark could ignite flames and fires. Under natural circumstances, high temperature and low humidity are favorable causes for fire to ignite. Environmentally caused fires are strenuous to control while anthropogenic or man related causes are relatively easier to control. Some common human caused forest fires are land clearing and deforestation and for the purposes of farming.

Forest fires contribute in the emission of gases and particulate matter which are hazardous to human health and well-being. These gas emissions and resultant ash can cause air pollution which can be transported over thousands of kilometers with the help of extreme dry weather, strong winds and intense fires that could travel above the atmospheric boundary layer. One particular natural hazard that has caused concerned among the South East Asian countries is trans-boundary haze pollution. This issue has been a recurrent occurrence of severe fires and haze pollution in the late 1990s due to a large scale of slash-and-burn practices in Indonesia, especially from the provinces of South Sumatra and Riau in Indonesia's Sumatra Island, and Kalimantan in Indonesian Borneo.

Indonesia is a country that has significant frequencies of forest and land fires every year. The arrival of the dry season witnesses the burning of forests and land in Sumatra and Kalimantan. This is the time where trees were seen scorched and the ecosystem severely damaged by raging fire. Thick clouds of smoke emitted above the forest will reveal the burning area over a distant that could reach neighboring countries. This fire disaster can be considered a cyclical event where it occurred almost yearly in this country which has become a global concern at some point. Certainly, this has become an uproar to neighboring countries concerned when health and lifestyle is greatly affected. The most severe string of fire events occurred in Sumatra and Kalimantan with a distribution span of more than 4,000 kilometers (thestraitstimes.com, 2019).

Central and local governments are made to bother putting out the fire. Various methods are used to overcome the annual problem. The fire brigade team (damkar) was immediately dispatched to the location of the fire. Then to back up, the damkar team was assisted by the Indonesian Air Force. Damkar cars and special aircraft were deployed so that the hotspots were extinguished. Cubic water is sprayed to put out the fire.

The Straits Times (2019) alleged that fires are set by farmers whose clear intention is to clear up their formerly cultivated land for the coming new season to harvest new plots of vegetation. Rasyid (2014) said there are two factors that can cause forest and land fires. First, the natural factor is the influence of El-Nino which causes prolonged drought so that the plants become dry. If the dry plant is hit by sparks, it will burn because the dried plant is a potential fuel. Sparks that appear on the surface or from other combustion intentionally or unintentionally can cause fires below and surface fires. 
The El Nino factor has often disrupted the agriculture sector through episodic patterns of precipitation and atmospheric circulation triggering extreme climate events around the globe. Disaster from the El Nino has brought about weather related hazards such as flood and drought; drought being the main concern of this paper. Droughts are hyperbolic hydrological and meteorological events that can severely impact natural environment, especially the fire forests.

Second, human activity factors that can cause forest and land fires include the creation of campfires in the forest when the embers of the campfire were not extinguished fully. Usually HTI companies do land clearing by uncontrolled slash and burn activities. Moreover, if this activity is carried out on settlements, then forest fires and vulnerable landslide can easily occur. The fire that ignited may be due to throwing away cigarette butts that are still burning carelessly or due to the use of equipment and machinery that can spark fire.

Forest and land fires have an adverse impact on the surrounding community. Medically, the effect will be on human respiratory system. Carbon emissions contained in smoke is very dangerous for breathing which could be fatal. If left unchecked, it not only hurts but threatens people's lives. These forest fires produce carbon emissions released into the atmosphere. The most prominent, the adverse effects of forest and land fires are smog that disrupts health and land, sea and air transportation systems. (Cahyono et al., 2015)

In addition, forest and land fires also have an impact on forest ecology. Lush forests become bare because the trees that grow in the forest area are engulfed in flames. As a result, ecosystems in the region disrupted. The economic loss is another impact of the forest fire due to the loss of benefits from the potential of the forest that has been used to meet the needs of the community. Trees are processed for the purposes of building materials, food ingredients, and medicines, as well as animals to meet the need for animal protein and recreation. Other losses include a reduction in forest area, unavailability of clean air produced by forest vegetation and loss of forest functions as a regulator of water systems and prevention of erosion (Rasyid 2014).

Forest and land fires are a source of disaster for other countries. Malaysia and Singapore are two neighboring countries which were affected by forest and land fires in Indonesia. Black smoke in Sumatra were seen over the Malacca Strait to the two neighboring countries. Likewise in Kalimantan, thick smoke crossed the border into Malaysia in the East.

Raffles Panjaitan from the Ministry of Environment and Forestry (Reuters, 2019) said 857,756 hectares of land burned until the end of September 2019. This figure is higher than in 2018 which was only 529,267 hectares. Since 2015, land fires in Indonesia have reached 2.6 million hectares. Suryani (2012) said that forest fires in Indonesia are considered regional and global disasters. This is caused by the impact of forest fires that have spread to neighboring countries and the gases resulting from combustion emitted into the atmosphere (such as $\mathrm{CO} 2$ ) have the potential to cause global warming.

Forest and land fires are annual cases that began to erupt from June to October. The governments of Malaysia and Singapore often protest the handling of this issue to the Indonesian government. The Malaysian Ministry of Environment noted the impact of the 2007 smoke was worse than in 2006. Poor air quality was spread in 32 regions of Malaysia. 
The Malaysian government declared a state of emergency around Kuala Lumpur and announced emergency measures such as closing schools and asked residents to wear masks (Suryani 2012)

The annual disaster also attracted the attention of the media, both at home and abroad. For the media, forest and land fires that cross national borders are a big issue. Zulmi (2017) said the environment will always be the object of media coverage. Environmental issues that occur in it are often the main focus in the news. Especially if the fire affects other countries, then it has high news value. Galtung \& Ruge (1965) said the media paid great attention because of the news value factor. Newspapers, television and other media present news because they have events that contain news value.

The media will play the issue as a sale. Editors who have the authority to produce news will process environmental issues as big news. Through agenda setting, the editorial role influences the production process to the audience (Straubhaar et al: 2012, 420). Media republika.com and bharian.com are two portals that broadcast news of forest and land fires in Sumatra and Kalimantan. Both have similarities and differences in presenting news of forest and land fires. Apart from the reason for the high news value of forest and land fires, both are believed to have interests in the reporting.

\section{PROBLEMS}

People now have access to fast information through the internet. On one side, people's speed in accessing news is the advantage of online media. Within minutes, the news was presented in cyberspace. But on the other hand, people also easily accept information whose truth value is still unclear. The media spreads the news to build opinions according to their interests.

Forest and land fires in Sumatra and Kalimantan are big cases that receive special attention by the mainstream media. Domestic and international media also broadcast forest and land fires that occurred on the two main islands of Indonesia. They consider forest and land fires in Indonesia to have a wide impact on neighboring countries, Malaysia and Singapore. Herawati and Santoso (2011) said the fire was an issue that attracted both local and global attention.

The consideration of the value of news is an important factor for the media. Forest and land fires are considered to fulfill several key elements of news values such as impact, proximity, conflict, figure-set, outside the actual and important aspects. Republika.co.id and bharian.com.my are networking media that pay attention to forest and land fires in Sumatra and Kalimantan. According to Shoemaker and Reese (1996), news value is an element addressed to an audience.

Republika.co.id and bharian.com.my have reasons for broadcasting intensely cases of forest and land fires in Indonesia. Although they are both media portals, they have differences in reporting on forest and land fires. Republika.co.id further explores the causes of fires and blackout measures. This media describes the origin of the fire and the design of the handling. Instead bharian.com.my further emphasizes the fires as well as moral messages about the fire.

Republika.co.id is the Indonesian media portal under the auspices of the Republika.co.id media while bharian.com.my is the Malaysian media portal under the Harian Harian group. When a long dry season hits Indonesia in 2019, both broadcast news of forest and land fires. In addition, republika.co.id also from the aspect of sources gave space from 
various parties to comment on this case. Forest and land fire stakeholders were involved through their ideas in this case. Instead bharian.com.my gives more space to the government.

Under these conditions, republika.co.id and bharian.com.my developed different news construction for the case of forest and land fires. Both these portals have a way to package forest and land fire reports. There is an emphasis on certain issues and setting aside certain issues. As the technical implementer of the news, the editorial republika.co.id and bharian.com.my process events that occur in the field. Through reporters and editors, editors select the issues that will be broadcasted. The editor also creates the construction of an event.

In communication, what republika.co.id and bharian.com.my is doing is framing the news. Van Gorp (2010) says framing is a selection process of existing reality and makes it more prominent. Edelman (1997) says framing is a categorization to indicate how reality or facts are understood.

Both of them frame the cases of forest and land fires according to their respective construction. They choose what issues to broadcast or what issues are hidden. Then what theme is highlighted or what theme is obscured. They also determine who the resource person will comment on so that they can guess the ideas and ideas that will be conveyed by the resource person.

This study aims to describe republika.co.id and bharian.com.my framing news on forest and land fires in Sumatra and Kalimantan.

\section{LITERATURE REVIEW}

Social studies that discuss forest fires in Indonesia are mostly done by social researchers. Suryani (2012) studied the adverse effects of forest fires on the Indonesia-Malaysia border. She discussed strategies and policies adopted by the Indonesian government to reduce the haze generated by forest fires at the border. Her study aims to provide information and input for the government in pursuing and formulating policies to deal with haze as a result of the patience of forests on the border.

Forest fires are bad for the community and the environment. The resulting impact is; first, health and the environment. In Sumatra, especially Riau, local residents affected by forest fires for more than one week were stricken with respiratory infections (ARI). The immune system of local residents also decreased due to complaints of cough, runny nose, and high body temperature.

Second, it affects the economic and transportation sectors. The impact of forest fires indirectly affects community economic activity. People's income is decreasing due to increased household expenditure. Transportation services are disrupted and have an impact on community business activities. Transportation disruption in the form of visibility is interrupted during travel.

Third, cross-border pollution. Forest fires in Sumatra and Kalimantan have socioeconomic impacts on local communities. Moreover, the fire caused transboundary haze pollution to Malaysia and Singapore. Consequently, the two neighboring countries filed a protest with the Indonesian government on the grounds of a threat to basic human needs. The air breathed by citizens of the two nearest countries was polluted by the smoke of patience.

This study offers preventive measures including completing software in the form of guidelines and technical guidelines for prevention, and combating forest fires, completing hardware in the form of forest fire prevention and extinguishing equipment, holding training on forest fire control for government officials, personnel of State-Owned Enterprises 
(BUMN) and forestry companies and communities around the forest, and campaigns and counseling through various apples to control forest fires.

Cases of forest fires in Sumatra and Kalimantan and Papua were also carried out by Cahyono et al (2015). They used secondary time series data from 1969-2012 and analyzed the data using the econometrics model. Their study aims to find out the factors that influence the extent of forest and peat fires in Indonesia.

The research of Cahyono et al (2015), produced a variety of factors that had an effect on the causes of forest and peat fires. The influencing factors include the price of logs, CPO export prices, el nino, the Ministry of Forestry's budget, the economic crisis and the number of hotspots. The major influence on the area of forest and peat fires is the number of hotspots. Control of the number of hotspots significantly reduce the area of forest fires. This study considers the need for a paradigm shift in forest fire control from forest fire suppression activities to preventive efforts. Hotspots as an early indication of forest fires must be prevented as a source of fire.

Study of media framing was cnnducted by Sannusi and Seman (2018). Their study discussed the issue of religious liberalism in Malaysia. The object of his research focuses on the news of religious liberalization published in Malaysiakini media, Envoys Online and Sinar Online. This study sees the three media framing the news of religious liberalization through the highlighting and selection of issues.

For methodology, both use the Entman framing model consisting of four elements, namely defining the problem, interpreting the causes of the problem, making moral judgments, and problem-solving recommendations. G25 articles published by Envoy Online, Sinar Online and Malaysiakini were analyzed. Entman (1993) says framing is related to the choice of issues and the prominence of a reality over other realities. Of the various issues, the media will choose what issues will be presented to the public. The media also has the authority to highlight certain issues and realities.

The results of this study indicate that the media provides a definition of religious liberalism as an effort to exclude religion and are not happy with religious life, and reject laws that restrict human rights. The election and prominence made by the media on this issue make the concept of liberalism understood as a dangerous understanding for Muslims. Envoys Online and Sinar Online maintain Islam based on institutionalization despite having different media ownership backgrounds. Continuing the analysis of framing, can be seen clearly what is in the minds of media managers. Is the published news intended to inform, just report or cause controversy?

\section{METHODOLOGY}

This study is qualitative approach in nature that illustrates certain aspects of a reality framed by republika.co.id and bharian.com.my. Framing the two media created a new reality for forest and land fires in Sumatra and Kalimantan. It is descriptive as it describes and explains the events in forests and land in Sumatra and Kalimantan. This study uses the framing analysis method with a constructionist perspective. This paradigm views that there is no objective reality but through a construction process known as framing. Therefore this study will describe the process of framing by republika.co.id and bharian.com.my on forest and land fire news. The model used is Entman (1993) with four elements, namely the definition of the root of the problem, interpretation of the causes of the problem, moral judgment, and problem solving recommendations. 
Entman (1993) himself divides framing into two major dimensions, namely the selection of issues and the highlighting of certain aspects of a reality. Pan and Kosicki (1993) divide framing into two main concepts namely the concept of psychoilogy which emphasizes how a person processes information in himself and the sociological concept that emphasizes how social construction of a reality. Whereas D'Angelo (2010) states that framing analysis is news that constructs reality through public life.

For this reason, the subjects of this study are the media republika.co.id and bharian.com.my. Both are media representative from Indonesia and Malaysia. The object of study is news on cases of forest and land fires in Sumatra and Kalimantan which are published on republika.co.id and bharian.com.my. The news was presented for six months, from the July-December 2019 edition.

At the initial stage, news was identified, then collected. This study managed to capture 47 news consisting of 25 news from republika.co.id and 22 news from bharian.com.my. The next step is called coding which based on Entman model. Researchers employed coders who are familiar about framing analysis and who understands coding procedures.

Related to the operational definition, four elements are used to find out how republika.co.id and bharian.com.my frame forest and land fire news. The four elements use the Entman model (1993), which is first, defining the root of the problem (define problems) which discusses the source of the fire. Where did the first spark come from? Second, interpreting the causes of the problem (diagnose causes) that is estimating the factors that cause the emergence of fire that has spread further. Third, moral judgment (moral judgment), namely important messages related to fire. Fourth, treatment recommendations, namely problem solving as an effort that must be taken to extinguish forest and land fires.

\section{FINDINGS AND DISCUSSION}

\section{Findings}

This study uses descriptive qualitative approach to framing news on the formation of forest and land fires in Sumatra and Kalimantan. The forest and land fire news were published in republika.co.id and bharian.com.my in the July-December 2019 edition. To find out how the two newspapers frame the news, this study applies the Entman framing model that emphasizes four important elements, namely the disclosure of the root causes, causes of problems, moral judgment, and recommendations.

\section{Republika.co.id Framing}

Media republika.co.id sees the root of the problem of forest and land fires; first, related to the sustainability of the lives of people who live around the forest area. They burn forests with the aim of making a living, not destroying nature. They have no other income except from farming. They opened new land in the middle of the forest by burning trees. This can be seen in the following news excerpt:

"... There are three factors that would not have been possible without humans carrying the fire. Forest fires are often related to plantation activities, corporations, and communities often clear land by burning forests. " (September 21, 2019 edition)

Besides the root of this problem can be seen in the following news excerpt: 
"... 99 percent of forest and land fires occur because of human activity, whether intentional or not. The basic problem of forest and land fires is the livelihoods of local communities in agriculture and plantations. " (September, 23 edition, at 20:53 WIB)

Which is followed by another excerpt:

"To clear forests and land, most people and plantation companies take shortcuts by burning them because they are cheap." (September, 23 edition, at 20:53 WIB)

"... peatlands actually have a function as swamps. However, because of human activity, canals on peatlands cause it to become dry and flammable. While the heat source is also caused by human activity. " (September, 23 edition, at 20:53 WIB)

Second, the interests of certain companies that exploit peat land. These corporations intentionally burned peatlands for their business interests. This is evidenced in the following news text:

"... the police have identified 249 individual perpetrators as suspects causing forest and land fires (forest and land fires). Six corporations named as suspects in forest and land fires and being processed ..."(September 21, 2019 edition)

"The six corporations are handled by several regional police, namely one corporation handled by Riau Regional Police, one corporation in South Sumatra Regional Police, one corporation in Jambi Regional Police, one corporation in East Kalimantan Regional Police, and two corporations in West Kalimantan Regional Police. ... The National Police Criminal Investigation took to the location of the fire to help the local police target the culprits. " (September 21, 2019 edition)

For the element of interpretation that causes the problem, republika.co.id views the case of forest and land fires as a result of; first, the opening of plantation land by communities and corporations. They make the forest as a job. With wages from the company's cukong, they are willing to burn the forest as evidenced in the following news excerpt:

"Forests for inland residents are like the cape of life. Without taking part of the forest land, they will not be able to make ends meet. "And this method has existed since our ancestors hundreds of years ago." (Monday edition 21 Oct 2019 05:05 WIB)

Second, burning peat. Peat is very flammable but difficult to extinguish as seen in the following news quotes:

"The peat ecosystem is damaged because there are plantations both from the community and corporations. They usually change the peat from wet to dry so it can be planted. " (September 21, 2019 edition)

"Burning peatlands are difficult to extinguish because hotspots have spread into the ground, so fires often reappear because they are not completely extinguished if only watering is done from the ground surface." (September 21, 2019 edition)

In addition, other quotes can be seen in the following news:

"... Although water bombing has been carried out for seven days with three helicopter units, forest and land fires have not been extinguished. That proves that suppressing 
forest and land fires on peatlands is difficult to extinguish. " (September 25, 2019 edition)

Third, the lack of local government support for fires. Although the central government has conditioned outages, forest and land fires are difficult to overcome without local government involvement as seen from the following news excerpt:

"President Jokowi has reprimanded the regional government in Riau Province, which is considered not to support efforts to deal with forest and land fires. As a result the fire spread to tens of thousands of hectares and caused a thick haze of smoke. " (September 23, 2019 edition)

"We will add troops. But again, if there is no local government support, this is a big job that is difficult to complete. Our experience in previous years like that. The key is to prevent it, don't let any hotspots appear. " (September 23, 2019 edition)

Fourth, there is climate change. Republika.co.id also makes climate change a trigger for fire to occur. The prolonged dry season is susceptible to warming, which causes fires as witnessed in the following news excerpt:

"Indonesia is currently facing land and forest fires in various regions in Sumatera and Kalimantan which are getting worse due to the effects of climate change." (September 24, 2019 edition, 09:28 WIB)

From the aspect of moral judgment, first, republika.co.id focuses on law enforcement. The government needs to sanction indiscriminate arsonists. They must be dealt with firmly to account for their actions before the law. Morally, the effects of ecology must be known by the community so that they protect the forest and its environment. This law enforcement step can be seen in the following news excerpt.

"... the police have identified 249 individual perpetrators as suspects causing forest and land fires (forest and land fires). Six corporations named as suspects in forest and land fires and being processed ..." (September 21, 2019 edition)

Furthermore, other evidence can be seen in the news quote:

"Burning garbage is also dangerous, especially the deliberate burning of private lands and plantations. The police said that they would take strict action against land burners. " (September 24, 2019 edition, 07:17 WIB)

"KLHK since 2015 has applied both administrative and criminal sanctions to corporations that violate these rules. He said he had also worked closely with law enforcement officials such as the police and the state high court to crack down on forest fires. " (Saturday edition Sep 212019 15:42 WIB)

Second, is building environmental awareness. Republika.co.id also encourages the importance of environmental awareness for the community. The environment is an important part of people's lives interacting with nature. This can be seen in the following news excerpt:

"Indonesia will even establish a special environmental funding facility to facilitate climate finance and support other environmental programs." (September 24, 2019 edition, 09:28 WIB) 
"The focus of preventing fires from happening again is very important, because if peatlands burn, it is difficult to extinguish." (Wednesday edition 25 Sep 2019 07:33 WIB)

"To prevent fires on peatlands, the function of peatland ecosystems as swamps must be restored. In addition, there needs to be community empowerment to plant crops suitable for peatlands. " (Monday edition 23 Sep 2019 20:53 WIB)

Third pro-environment policies. Republika.co.id considers the importance of policies that are pro-environment. The government may work on natural resources without ignoring the surrounding environment. This is evidenced in the following news excerpt.

"JK also explained Indonesia's efforts in taking various steps to tackle climate change. The effort starts with reducing greenhouse gas emissions with an ambitious target of 29 percent on its own, and up to 41 percent with international support until 2030. " (Tuesday edition Sep 242019 09:28 WIB)

"... Indonesia has also intensified its climate action, through a nature-based solution, by restoring 2 million hectares of peatlands and rehabilitating 12 million hectares of critical land by 2030 and intensively conserving mangroves and coastal areas. Indonesia is also undertaking an energy transition program by removing fossil fuel subsidies and setting mandatory biodiesel policies and building green fuel refineries. " (Tuesday edition Sep 242019 09:28 WIB)

While the problem solving recommendation side, republika.co.id emphasizes the first tactical handling through the empowerment of the available infrastructure. Artificial rain or water bombs, blocking canals or tank production plans are some of the ways to deal with fires. This can be seen in the September 23, 2019 edition of the news excerpt.

"... handling with a water bombing was apparently not very effective."

"... the application of weather modification technology by the Agency for the Assessment and Application of Technology, the Climatology and Geophysics Meteorological Agency and BNPB with the support of the TNI is even more significant in the handling of forest and land fires."

"In an effort to tackle forest and land fires, the government has also deployed around 50,000 land personnel and 48 helicopters and aircraft in six provinces."

Second, cooperation with outside parties. Republika, co.id, asked the Indonesian government to consider foreign aid for the extinction as proven in the following news excerpt:

"... to prevent fires on peatlands, the function of peatland ecosystems as swamps must be restored. In addition, there needs to be community empowerment to plant crops suitable for peatlands. " (September 23, 2019 edition, at 20:53 WIB)

"We brought alkon pumping machines, but here it is difficult to get water, so we help power to spray water from BPBD's hose." (September 24, 2019 edition, 00:40 WIB) "... various weather modification efforts have been made. Dozens of helicopter units were taken down. For South Sumatra, the highest number of units, namely nine helicopter units, of which seven for water bombing and two for patrol, were deployed.

" (September 25, 2019 edition)

Third, regular patrols. Another problem-solving recommendation for republika.co.id is to hold patrols regularly. Officers must monitor environmental safety by sending teams to the 
field. There must be no person who violates the forest. This can be seen in the following news excerpt:

"Another prevention effort is to patrol regularly and continuously. Siti said President Joko Widodo also emphasized the handling of forest and land fires through prevention efforts. " (Tuesday edition 22 Oct 2019 13:11 WIB)

\section{Bharian.com.my Framing}

Meanwhile, bharian.com.my sees the root causes of forest and land fire cases as a result of; First, it is carried out by unscrupulous forest burners. They are a group of people who depend their lives from forest products. They act as forest burners to open new fields. This can be seen in the following news excerpt:

"The Indonesian authorities are now in an effort to prosecute individuals who are found responsible for carrying out illegal burning activities to contribute to the phenomenon of frugality in Indonesia." (Tuesday, September 10, 2019 | 9:35 pm)

Second, the main source of forest and land fires comes from Sarawak, as alleged by Indonesian Environment Minister Siti Nurbaya. A strong wind blows from the Malaysian state into the Peninsula. This can be seen in the following news excerpt:

"The smoke (jerebu) that enters Malaysia, Kuala Lumpur, is from Sarawak and Peninsular Malaysia, and may also be part of West Kalimantan. Therefore, (Malaysia) should objectively explain it, "said Siti Nurbaya. (Thursday, September 12, 2019 | 10:02 am)

In the element of interpretation of the cause of the problem, bharian.com.my views cases of forest and land fires in Sumatra and Kalimantan as a result of; First, the number of hotspots. Widespread fires in the wilderness caused by the emergence of hotspots. Unexpectedly the hotspots spread so that they killed the surrounding trees as evidenced in the following news excerpt:

"The number of hotspots which increased by 124 from there was characterized as being strong enough to cause fires throughout the country, this morning." (Wednesday, 31 July $2019 \mid$ 8:19 pm)

"This situation applies after the number of hot group areas has increased in the area since a few days ago. This morning, more than 20 hot groups were impressed in West Kalimantan, with most of them operating close to the Malaysian-Indonesian border. (Wednesday, September 4, 2019 | 8:09 am)

"The impression of drought and the southwest monsoon season so far has sparked a very severe impact on the phenomenon of jerad fringe in Malaysia, even the summing up of hot groups in Kalimantan and Sumatra last week, respectively 811 and 247." (Tuesday, September 10, 2019|9:35 pm)

"Pekanbaru Meteorological Station reported that 448 heat groups were ordered across the entire island of Sumatra, including 154 heat groups recorded in eight regions of Riau, to cope with the air quality stage in the region." (Wednesday, September 11, $2019, \mid 11: 59 \mathrm{am})$ 
"Today the area of 'hotspots' or forest fire hotspots in Kalimantan increased to 1,188 compared to 480 overnight while in Sumatra it also increased to 431 to 387 . Comparatively there are only five heat groups in Malaysia today compared to seven overnight." (Thursday, September 12, 2019|2:01 pm)

Second, the wind factor. Strong gusts of wind from Indonesia helped trigger forest and land fires. The smoke that surrounds Sarawak is smoke originating from Kalimantan as evidenced in the following news excerpt:

"The wind that continues to blow from the direction of Borneo, Indonesia, worsening the situation of the cane in Sarawak," (Sunday, September 8, 2019| 9:13 am)

In terms of moral judgment, bharian.com.my sees first, the importance of law enforcement. Forest and land fires are carried out by certain parties. They damage the natural environment for the sake of ambition and interests. Therefore they must get sanctions for their actions. This is evidenced in the following news:

"Actually, the dependence of the state's collective cooperation in overseas is simply insufficient, as long as there is a company or entity, it causes no action taken. These people gain a fair profit but cause millions of people to suffer. " (Sunday, September $15,2019 \mid 11: 00 \mathrm{am})$

Second, openness Joko Widodo acknowledged the fires that occurred in Indonesia. These forest and land fires have brought disasters to other countries. This is evidenced in the following quote:

"I am sometimes ashamed. This week I want to go to Malaysia and Singapore. But, I know last week (last week) has become a 'headline' (headline), jerebu re-enter our neighboring countries. I 'check' (bush) What is this jerebu, it turns out smoke, "said Jokowi picked by local media." (Wednesday, August 7 2019| 12:48 pm)

"This year, the 'imported jerebu' returns even though Malaysia is not pointing fingers at Indonesia. However, at the beginning of last month, the President of Indonesia, Joko Widodo (Jokowi) himself admitted feeling ashamed to Malaysia and Singapore, who were also affected by the burning of forest fire in Indonesia. " (Sunday, September 15, 2019|11:00 am)

Finally on the element of problem solving recommendations, bharian.com.my emphasizes first, cooperation between countries. The Indonesian government needs to collaborate with other countries to overcome the problem of forest and land fires in Sumatra and Kalimantan. This is evidenced in the following news excerpt:

"The MSC expert countries have also agreed to increase cooperation in dealing with pollution from borderless canisters. Malaysia believes that all MSC expert countries are trying their best to resolve the jerebu problem at this time, "(Friday, 6 September $2019 \mid 2: 16 \mathrm{pm})$

"Actually, the dependence of the state's collective cooperation in overseas is simply insufficient, as long as there is a company or entity, it causes no action taken. These people gain a fair profit but cause millions of people to suffer. " (Sunday, September $15,2019 \mid 11: 00 \mathrm{am})$ 
Second, ratify the agreement. The governments of Indonesia and Malaysia consider the importance of ratification of the agreement related to the issue of haze in the border regions of the two countries as evidenced in the following news excerpt:

"In dealing with this borderline jerebu problem, ratification related to the Agreement to Address Sempadan Extermination Pollution Pollution (AATHP) which was sealed by 10 Asean countries in 2014 already exists but, it must be re-examined." (Sunday, September 15, 2019|11:00 am)

"MSC also repeats the commitment to achieve the objectives and principles of the ASEAN Agreement on Contamination of Flushed Sempadan and to achieve the target of" ASEAN Without Jerebu "by 2020. In addition, it will continue the program of capacity building and training in member countries in dealing with borderline canisters." (Thursday, August $82019 \mid 12: 19$ pm)

Third, tactical handling in the field. Media bharian.com.my see recommendations for solving problems through direct handling in the field. Forests and burned land must be addressed immediately without a long wait. Existing infrastructure was deployed so that the fire did not spread. This is evidenced in the following news excerpt:

"We are ready to cooperate if needed (by the Indonesian authorities), of course Bomba (JBPM) is willing to provide assistance (put out fires)," he told the media after the pre-launch of the Seventh Asia-Pacific Urban Forum (APUF7), here, today. " (Thursday, September 12, 2019|11:53 am)

"The process of hatching clouds will begin today in Sarawak to deal with the problem of increasingly narrow border rivers. .... the decision was decided by the cabinet last night following a situation of dust in an increasingly serious and dangerous country. He said, all relevant agencies were on standby to start the cloud hatching process as well as the initial monitoring was done. " (Thursday, September 12, 2019|2:01 pm)

"Sarawak on the 19th day of the month ... look at the situation if there are clouds to be hatched because sometimes when there are no clouds, the situation does not allow it to rain even though it has made a hatchery." (Monday, September 16, 2019 | 10: $10 \mathrm{pm})$

"... the kingdom is researching reserves to use dron to do cloud hatcheries, thus producing rain in an effort to reduce the impression of dust. We can use several dron to produce artificial rain, for example around Putrajaya which is between the hardest terejas. (Thursday, September 19, $2019 \mid$ 4:00 pm)

\section{Discussions}

Based on the findings obtained, republika.co.id and bharian.com.my share similarities and differences in attitudes in constructing cases of forest and land fires in Sumatra and Kalimantan. They frame reality according to their vision and mission.

At the root of the problem element, republika.co.id and bharian.com.my see forests as a source of life for local people. Those who live around the forest depend on the fields that are opened in their midst. Consequently they have to burn trees for farming. 
Both republika.co.id and bharian.com.my see the human side. Local people are only able to make a living through the natural resources available in the forest. A form of family responsibility, they are forced to cut down trees to open new fields.

Republika.co.id also focuses on burning peat as part of business. Local residents are lured by unscrupulous entrepreneurs to burn forests. Republika.co.id sees the interests of the company in utilizing citizens' services to smooth its business activities. By burning forests, business people exploit the natural resources of forests for economic purposes and motives.

While bharian.com.my accused Malaysian corporations of being "behind" the burning. Forest resources for them are a lucrative business opportunity. This media blatantly alleged that Malaysian companies have an interest in forest activities in Sumatra and Kalimantan.

For the interpretation of the causes of the problem, republika.co.id and bharian.com.my have different attitudes. Republika.co.id blamed the clearing of plantation land by communities and companies as the cause of the fire. They burn forests for personal or corporate interests. People burn trees to make ends meet for their kitchen needs. In addition, as a request of the company that pays.

Then the carelessness of residents who burn peat. They did not think that burning peat would be fatal. The fire that is under the ground does not go out but continue to spread and expand. Next, republika.co.id views the reluctance of local governments to synergize with the central government in dealing with fires. Local government is considered not responsive in putting out fires. Local government support is very slow in taking a stand. Beyond that is extreme climate change. A prolonged dry season has the potential to create a hotspot. El nino is very prone to causing forest fires.

While bharian.com.my see the cause of the fire is at the hotspots in the forest. El Nino creates hot spots that spread in various places. Without blackouts, the hotspots then enlarge. In addition, this media also blamed the wind factor as having a role. His gust helped enlarge the sparks.

In the element of moral judgment, republika.co.id and bharian.com.my have the same attitude. Both consider the need for law enforcement. The Indonesian government must strictly enforce the law for arsonists.

Republika.co.id also considers the importance of building awareness for the community. The government must campaign for the environmental love movement. Citizens' awareness of the importance of forests must be socialized. Then the central government created a pro-environment policy. Exploration of natural resources must be in line with environmental conservation. Do not let nature be exploited without thinking about the environmental impact.

While bharian.com.my, see the openness of the Indonesian government to accept offers of assistance from foreign countries. Don't let the fire drag on without more serious handling. The Indonesian government needs to open up to get help from neighboring countries.

Finally, as a recommendation for solving the problem, both republika.co.id and bharian.com.my consider the need for tactical handling in the field to be scattered and improved. Artificial rain, canal blocking, and other things were done immediately as an early effort to put out the fire. In addition, cooperation and assistance from other countries. The two governments must ratify the agreements that have been made together, especially those related to cross-border issues. Beyond that, republika.co.id proposes periodic patrols by 
activating an environmental monitoring team. They are tasked with monitoring the situation around the forest. The explanation can be simplified in the table below.

Table Framing republika.co.id and bharian.com.my

\begin{tabular}{|l|l|l|}
\hline \multicolumn{1}{|c|}{ Element } & \multicolumn{1}{|c|}{ Republika.com } & \multicolumn{1}{c|}{ Bharian.com.my } \\
\hline Define Problems & $\begin{array}{l}\text { - Community livelihoods in the forest by } \\
\text { burning land } \\
\text { - Burning peat areas for business purposes }\end{array}$ & $\begin{array}{l}\text { - Malaysia's land burner and company } \\
\text { - Fires originated in Sarawak and the } \\
\text { peninsula }\end{array}$ \\
\hline Diagnose Cause & $\begin{array}{l}\text { - Burning peat } \\
\text { - Clearing of plantation land by } \\
\text { communities and corporations } \\
\text { - There is no local government support }\end{array}$ & $\begin{array}{l}\text { - The number of hotspots } \\
\text { - Wind blowing factors from Kalimantan }\end{array}$ \\
\hline Moral Judgenent & $\begin{array}{l}\text { - Climate change impacts } \\
\text { - Law enforcement } \\
\text { - Build environmental awareness }\end{array}$ & $\begin{array}{l}\text { - Law enforcement } \\
\text { - Openness of the Indonesian } \\
\text { government }\end{array}$ \\
\hline Recommendations & $\begin{array}{l}\text { - Pro-environment policies } \\
\text { - tactical handling } \\
\text { - Foreign cooperation and assistance } \\
\text { - Regular patrol } \\
-\end{array}$ & $\begin{array}{l}\text { - Cooperation and ratification of } \\
\text { agreements to deal with pollution of } \\
\text { borderless canisters } \\
\text { - Tactical handling }\end{array}$ \\
\hline
\end{tabular}

\section{CONCLUSION}

This study concludes that the root cause of forest and land fires in Sumatra and Kalimantan, republika.co.id and bharian.com.my, sees local people doing it for their daily needs. In addition, there is the role of certain corporate actors who have business interests in forest resources. This corporation provides wages to residents to launch their business activities. In terms of problem interpretation, moral assessment, and problem solving recommendations, republika.co.id is more technical, systematic, and detailed looking at cases of forest and land fires than bharian.com.my which is normative by merely scrutinizing on technical aspects.

\section{REFERENCES}

Cahyono, S. A., Sofyan, P. Warsito., Wahyu, Andayani., Dwidjono, H. Darwanto. 2015. Faktor-Faktor yang Mempengaruhi Kebakaran Hutan di Indonesia dan Implikasi Kebijakannya. Jurnal Sylva Vol. 3 No. 1, 103-112.

D'Angelo, P. (2010). Arriving at The Horizons of News Framing Analysis, In Doing News Framing Analysis (pp. 357-368). New York: Routledge.

Edelman, Murray. 1997. Contestable Categories and Public Opinion. Political Communication. Vol. 10. No. 3.

Entman, Robert. 1993. "Framing: Toward Clarification of a Fractured Paradigm." Political Communication. Vol 43. No.4.

Galtung, J., \& Ruge, M. Holmboe. 1965. The Structure of Foreign News. Journal of Peace Research 2: 64-91. 
Gorp, B. V. (2010). Strategies to take subjectivity Out of Framing Analysis. In Doing News Framing Analysis, Empirical and Theoritical Perspectives (pp. 17-42). New York: Routledge.

Herawati, H., \& Santoso, H. 2011. Tropical forest susceptibility to and risk of fire under changing climate: a review of fire nature, policy and institutions in Indonesia. Forest Policy and Economics 13: 227-233.

https://www.reuters.com/article/us-southeast-asia-haze/area-burned-in-2019-forest-fires-inindonesia-exceeds-2018-official-idUSKBN1X00VU, with title Area burned in 2019 forest fires in Indonesia exceeds 2018 , edition October $21^{\text {st }} 2019$.

https://www.straitstimes.com/asia/se-asia/forest-fire-emissions-from-indonesia-worse-thanamazon-eu, with title Forest fire emissions from Indonesia worse than from Amazon: EU, edition November $27^{\text {th }}, 2019$.

Pan, Zhongdang \& Gerald, M. Kosicki. 1993. "Framing Analysis: An Approach to News Discourse." Political Communication. Vol. 10. No.1.

Rasyid, Fachmi. 2014. Permasalahan dan Dampak Kebakaran Hutan. Jurnal Lingkar Widyaiswara (www.juliwi.com). Edisi 1 No. 4, Oktober - Desember 2014, p.47 - 59. Paper ini dipresentasikan pada Lokakarya Regional Ikatan Widyaiswara Indonesia (IWI) Provinsi Banten tanggal 10 - 11 November 2014 di Patra Jasa Anyer Beach Resort, Serang.

Shoemaker, P. J. \& Reese, S.D. (1996). Mediating the Message: Theories of Influence on Mass Media Content, Secobd Edition, New York: Longman.

Straubhaar, J., Larose, R., \& Davenport, L. (2012). Media Now, Understanding Media, Culture, and Technology. Boston: Wadsworth.

Suryani, A. S. 2012. Penanganan Asap Kabut Akibat Kebakaran Hutan di Wilayah Perbatasan Indonesia. Jurnal Aspirasi Vol. 3 No. 1, 59-75.

Zulmi, Febrina. 2017. Keberpihakan Media terhadap Isu Pelestarian Lingkungan Hidup. Jurnal KATA: Vol. 1, No. II, 101-108.

\section{About the authors}

Muhammad Ruslan Ramli is a lecturer in Communication Science at the Faculty of Communication Sciences, Esa Unggul University, Jakarta. his research studies focus on media and communication studies. Email: ruslan.ramli@esaunggul.ac.id

Dasad Latif is a lecturer in Communication Science at the Faculty of Social and Political Sciences, Hasanuddin University, Makassar. Email: dasadlatif@ymail.com 
Youna Chatrine Bachtiar is a Communication Science lecturer at the Faculty of Communication Sciences, Esa Unggul University, Jakarta. research studies are more focused on media and communication studies. 